\title{
PARAGÊNESE E SUCESSÃO MINERAL NAS DIFERENTES ETAPAS DA EVOLUÇÃO DA MINERALIZAÇÃO Cu-Pb-Zn DO DISTRITO DE CAMAQUÃ, RS
}

\author{
ROSICLER VEIGEL* e MARCEL AUGUSTE DARDENNE*
}

\begin{abstract}
PARAGENESIS AND MINERAL SUCCESSION IN THE DIFFERENT STAGES OF THE $\mathrm{Cu}-\mathrm{Pb}-\mathrm{Zn}$ MINERALIZATION AT THE CAMAQUÃ DISTRICT, RS. The sulfide mineralization of die Camaquã Mines $(\mathrm{Cu})$ and of the Santa Maria Deposit $(\mathrm{Pb}-\mathrm{Zn})$. State of Rio Grande do Sul, southern Brazil, is associated with red bed conglomerates and sandstones, deposited hi an alluvial fan environment at the end of the Brasiliano Event. The non opaque cement and ore mineral analysis allow to identify four main phases hi the mineralization process occurred after the sedimentation: the eodiagenetic and mesogenetic phases are represented by the formation of hematite I-rutile and pyrite I-marcasite, respectively; the late diagenetic to epigenetic phase has occurred at deep burial levels and it was superimposed to the least non opaque cements. It comprises the galena-sphalerite-chalcopyrite paragenesis in the Santa Maria Deposit and the pyrite Il-chalcocite I-bornite I-chalcopyrite paragenetic sucession in the Camaquã Mines; the paleo-oxidation/cementation phase took place after uplift and unroofing. It is well observed in the Camaquã Mines where the previous sulfide phases were altered and replaced by die hematite IT-bomite Il-chalcocite TI-covellite. In the Santa Maria Deposit occur the hematite n-stephanite-chalcocite II-covellite-native silver paragenesis; and the tectonic remobilization phase of the previous ore cements has occurred during bed tilting and leaded to the formation of pvrite-bomite-chalcopyrite-quartz and hematite-bornite-chalcocite-barite-calcite veins in the Camaquã Mines, and only of veinlets with galena-sphalerite in die Santa Maria Deposit. The deposition of die Guaritas Formation occurred when die mineralization process had finished, i.e. after the tilting of die Bom Jardim Group beds.
\end{abstract}

Keywords: Red beds, Upper Proterozoic, $\mathrm{Cu}-\mathrm{Pb}-\mathrm{Zn}$ mineralization, diagenetic evolution, supergenic enrichment.

\begin{abstract}
RES UMO A mineralização sulfetada das Minas do Camaquã $(\mathrm{Cu})$ e da Jazida Santa Maria $(\mathrm{Pb}, \mathrm{Zn})$ está associada a arenitos e conglomerados do tipo red bed depositados como leques aluviais no final do Ciclo Brasiliano no Rio Grande do Sul. A análise dos cimentes transparentes e opacos permite definir quatro etapas principais para a evolução da mineralização após a sedimentação: as fases eodiagenética e mesogenética são representadas pelas associações hematita I-rutilo è pinta I-marcassita, respectivamente; a fase diagenetica tardia a epigenética ocorre sob soterramento profundo sobrepondo-se aos últimos cimentos transparentes e envolve as paragêneses galena-esfalerita-calcopirita na Jazida Santa Maria e, sucessivamente, pinta II-calcocita I-bornita I-calcopirita nas Minas do Camaquã; a fase de paleoxidação/cimentação se desenvolve após importante soerguimento e erosão da pilha sedimentar. É bem observada nas Minas do Camaquã, onde as paragêneses anteriores são substituídas por hematita n, bornita II, calcocita II e covellita. Na Jazida Santa Maria, a sucessão é hematita II-stephanita-calcocita II-covellita-prata nativa; e a fase de remobilização tectônica dos cimentos das fases anteriores na forma de filões, veios e vênulas é concomitante com o basculamento e/ou arqueamento das camadas, sendo caracterizada pelas seguintes associações: pirita-bornita-calcopirita-quartzo e hematita-bomita-calcocita-barita-calcita nas Minas do Camaquã e esfalerita-galena na Jazida Santa Maria. A deposição discordante da Formação Guaritas ocorreu depois do encerramento da mineralização sulfetada, isto é, após o basculamento das unidades do Grupo Bom Jardim.
\end{abstract}

Palavras-chaves: Red beds, Proterozóico Superior, mineralização $\mathrm{Cu}-\mathrm{Pb}-\mathrm{Zn}$, evolução diagenética, enriquecimento supérgeno.

INTRODUÇÃO O Distrito $\mathrm{Cu}-\mathrm{Pb}-\mathrm{Zn}$ de Camaquã localiza-se na porção centro-sul do Estado do Rio Grande do Sul (Figs, 1 e 2). A mineralização sulfetada é associada a conglomerados e arenitos do tipo red bed pertencentes ao Membro Vargas do Grupo Bom Jardim (Ribeiro et al. 1966) e depositados em um sistema de leques aluviais costeiros no final do Ciclo Brasiliano (Jost 1984, Fragoso César et al. 1985). O distrito compreende dois principais depósitos: nas Minas do Camaquã o minério é essencialmente de cobre, as encaixantes são principalmente conglomerados grossos e predomina o minério filoniano remobilizado sobre o disseminado. Na Jazida Santa Maria, a mineralização é dominantemente $\mathrm{Pb}-\mathrm{Zn}$ com $\mathrm{Ag}$ subordinado, as encaixantes são arenitos e conglomerados finos, e o minério conhecido é quase exclusivamente disseminado.

Em ambos os depósitos, a mineralização está no mesmo horizonte estratigráfico do Membro Vargas e são correlacionáveis cinco níveis litológicos bem definidos (Figs. 3 e 4): Arenito Inferior, Conglomerado Inferior, Arenito Intermediário, Conglomerado Superior e Arenito Superior. Os espessos pacotes de conglomerados grossos das Minas do
Camaquã acunham e transicionam lateralmente para ruditos de granulometria menor, em camadas mais finas e com intercalações arenosas mais desenvolvidas, como ocorre na Jazida Santa Maria. São reconhecidas fácies de leque e planície aluvial, sistemas fluviais entrelaçados e frente deltaica (Faccini et al.1987).

A presença de "cobre sedimentar" associado aos membros Vargas e Mangueirão, o qual teria sido parcialmente remobilizado pelos falhamentos noroeste formando filões, foi mostrada pelos trabalhos de Ribeiro (1978 a, b) e Teixeira et al. (1978). Paralelamente, a descoberta da Jazida Santa Maria veio consagrar a importância da mineralização disseminada essas rochas sedünentares (Badi 1983).

Propõe-se, neste trabalho, um modelo genético para essas mineralizações $\mathrm{Cu}-\mathrm{Pb}-\mathrm{Zn}$, formulado a partir da integração de dados de sedimentologia, diagênese e microscopia de minerais opacos. As características e a evolução textural do minério durante o processo de mineralização são descritas a seguir. Sobre a sedimentologia e a evolução diagenética do Membro Vargas, são discutidos em Veigel (1989). 


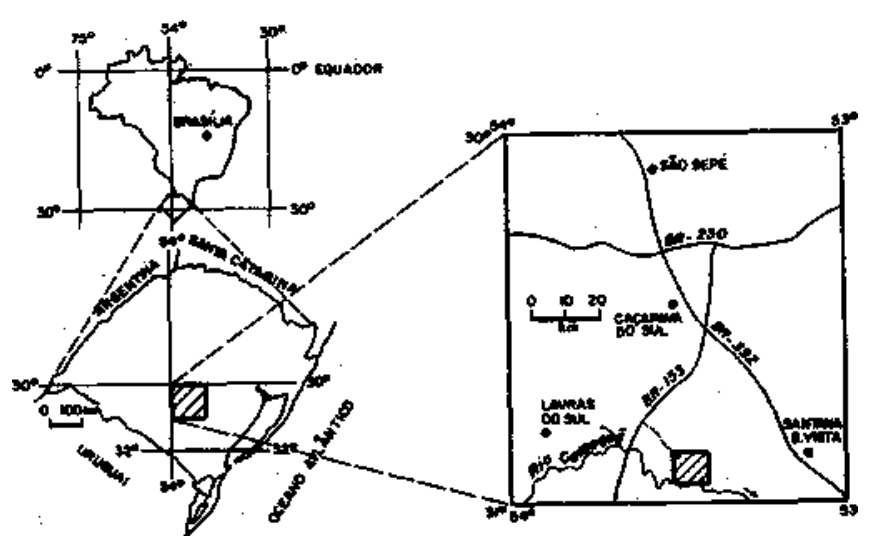

Figura 1 - Localização e acesso ao Distrito de Camaquã no Estado do Rio Grande do Sul

Figure 1 - Location and access of the Camaqui District in the State of Rio Grande do Sul

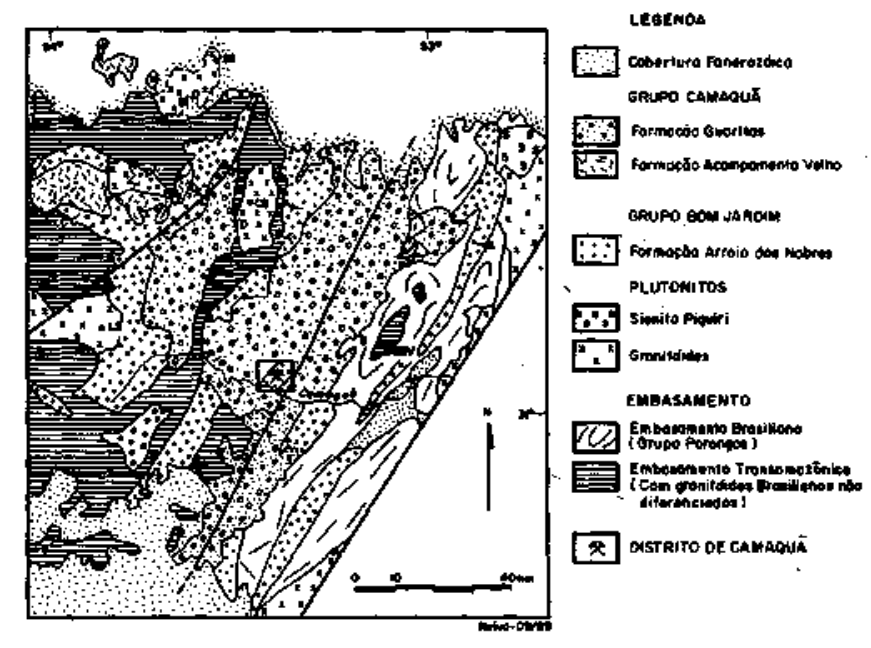

Figura 2 - Esboço geolbgico da porgäo centro-oeste do Estado do Rio Grande do Sul, destacando as unidades de Bacia do Camaquā

Figure 2 - Geological sketoh of the central-wet part of the Rio Grande do Sul Sture. shor ine the Carnagul Bevin units

\section{A MINERALIZAÇÃO E SUAS RELAÇÕES COM A} EVOLUÇÃO DIA̧GENÉTICA DO MEMBRO VARGAS Visando individualizar as diferentes fases de mineralização e estabelecer suas respectivas sucessões paragenéticas, foram estudadas 110 seções polidas do minério das Minas do Camaquã e da Jazida Santa Maria. A microscopia dos minerais opacos foi realizada concomitantemente com os estudos petrográficos de determinação da sucessão dos cimentes transparentes, o que permitiu uma visão global da evolução diagenética (Fig. 5). Assim, a sucessão paragenétíca dos cimentos opacos mostra quatro diferentes fases durante o desenvolvimento do processo de mineralização: eodiagenética e mesogenétíca; diagenética tardia a epigenética; paleoxidação/cimentação; e remobilização tectônica, que se relacionam com a evolução diagenética dos minerais transparentes das rochas (Veigel 1989).

$\mathrm{Na}$ eodiagênese houve a infiltração mecânica de argilas, a intensa alteração intra-estratal dos silicates de Fe e Mg e feldspatos, a formação de pseudomorfos de óxidos de ferro e de titânio sobre óxidos detríticos, a precipitação de hematita I e amplos crescimentos secundários de quartzo como níveis de silcrete. Em fácies transicionais redutoras formou-se pirita frainboidal.

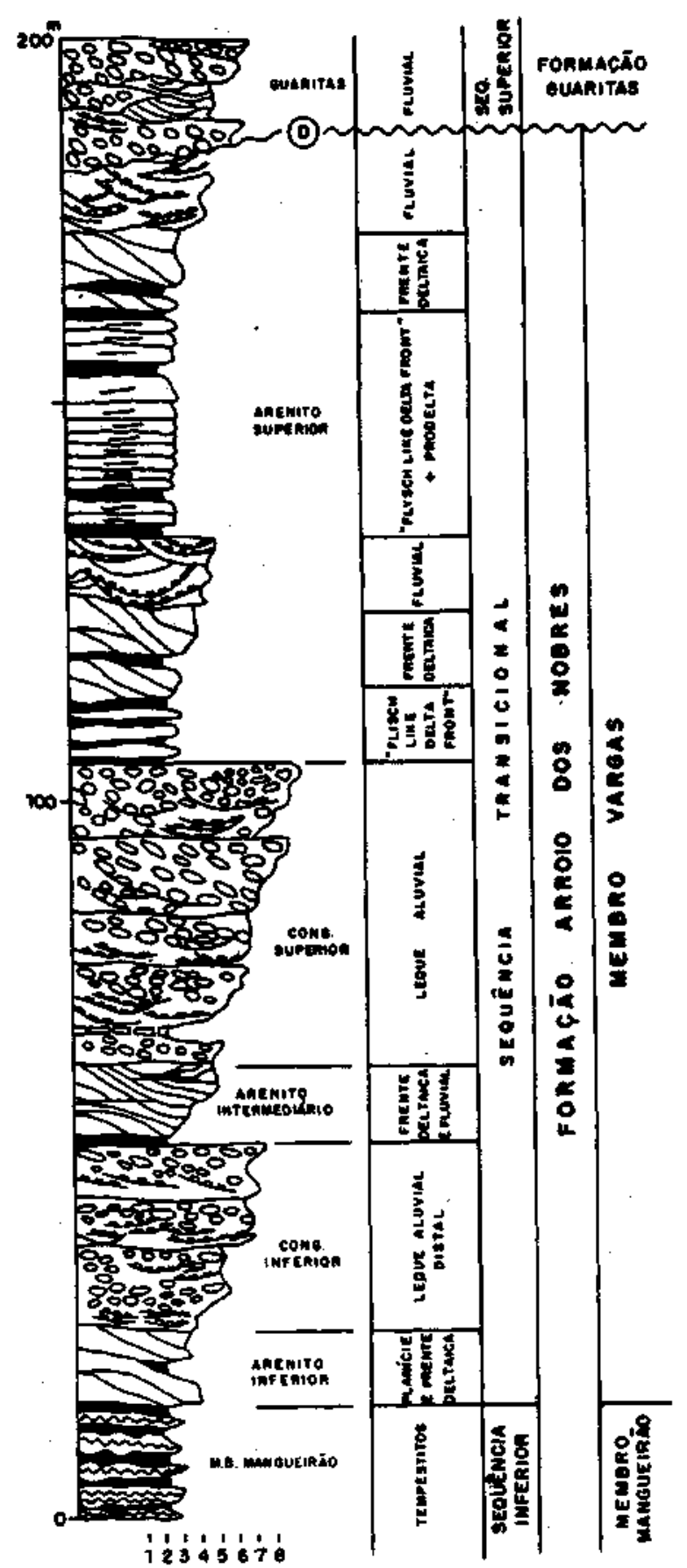

Figura 3 - Perfil colunar mostrando a discordância erosiva e angular entre o Membro Vargas e a Formação Guaritas Figure 3 - Colunar profile showing the erosional and angular uncorformity between the Vargas Member and the Guaritas Formation

Na mesogênese formaram-se crescimentos secundários sobre quartzo e feldspatos. Concomitante e subseqüentemente houve a evolução dos argilominerais detríticos para illita e/ou clorita e sua neoformação. Sucederam-se a precipitação da pirita I e a intensa cimentação por calcita, que substituíram corrosivamente os silicatos. Esse carbonato foi depois dissolvido, gerando importante porosidade secundária, e os poros abertos foram então delineados por cristais euédricos tardios de quartzo. Nessas profundidades e temperaturas mais elevadas, os feldspatos foram sendo progressivamente albitizados e localmente substituídos por óxidos de Fe e Ti, quartzo e apatita. 


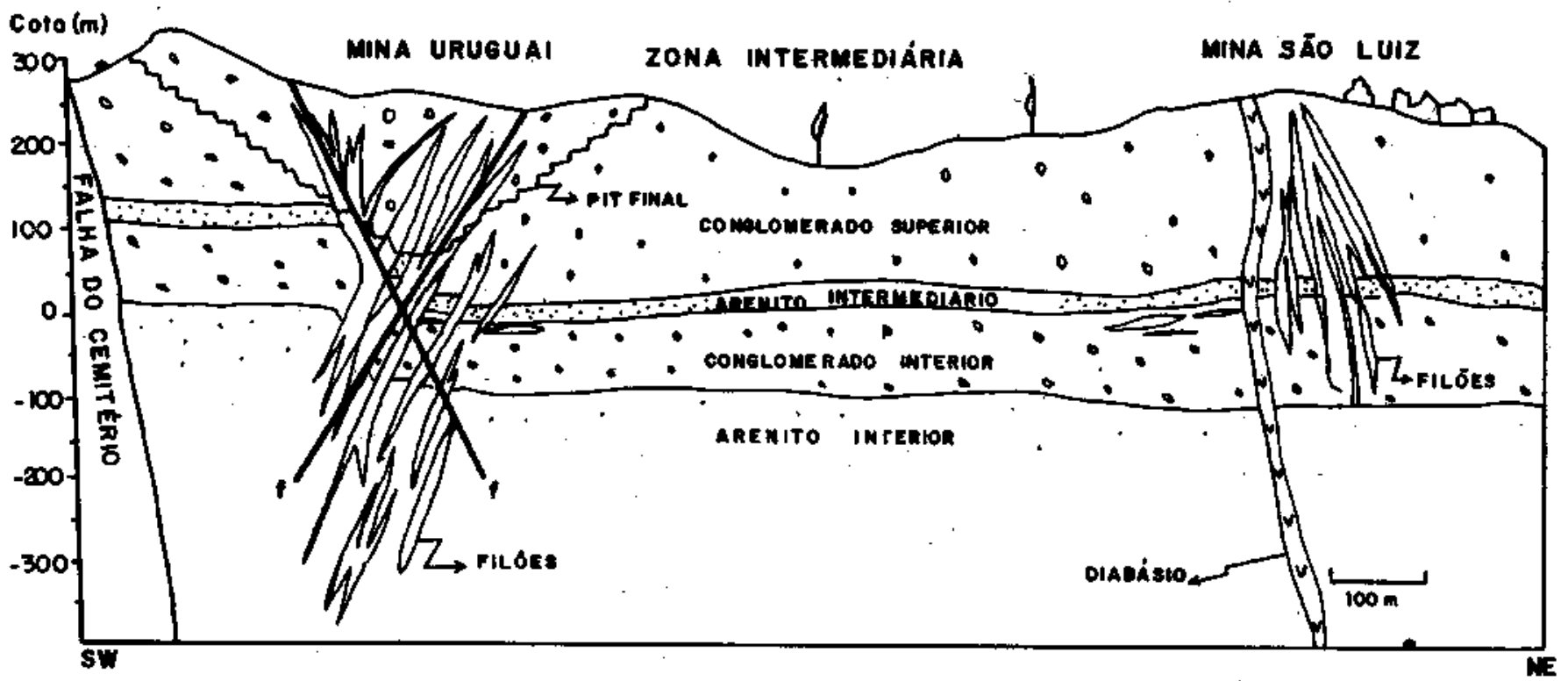

Figura 4 - Perfil geologico esquemático das Minas de Camaquä Figure 4- Schematic geological profilo of the Camaquil Mines

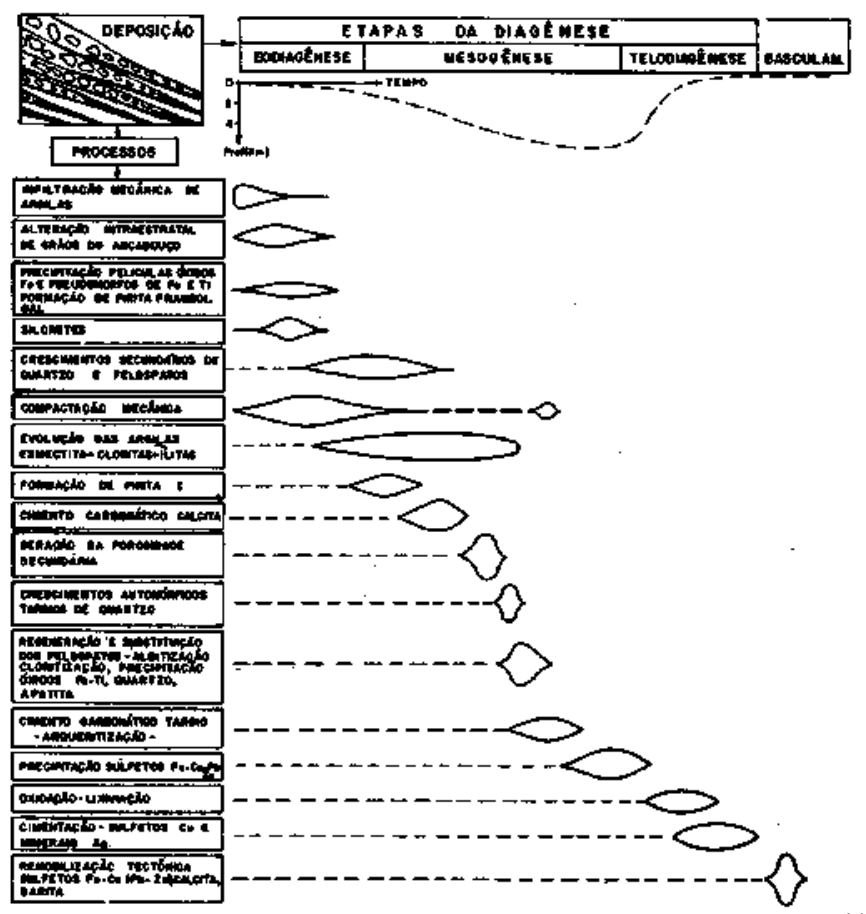

Figura 5 - A evoluçāo diagenética da Membro Vargas nas diferentes etapas de diagênese

Figure 5 - Vargas Member diagenetic evolution in the dैffferent diagenetic anges.

Paralelamente, ocorreu a precipitação de ankeríta na porosidade secundária ou substituindo a calcita remanescente. Somente então houve a introdução dos sulfetos de $\mathrm{Fe}, \mathrm{Cu}, \mathrm{Pb}$ e $\mathrm{Zn}$, que precipitaram passivamente na porosidade secundária ou foram corrosivos substituindo as fases precedentes, segundo a sucessão calcocita I-bornita I-calcopirita nas Minas do Camaquã e a paragênese galena + esfalerita \pm calcopirita na Jazida Santa Maria.

A telodiagênese transcorreu após o soerguimento e a remoção de espessa coluna de estratos com o desenvolvimento de uma zona de paleoxidação/cimentação. Os sulfetos anteriores foram alterados e substituídos por hematíta II, bornita II, calcocita II e covellita nas Minas do Camaquã e por hematíta II, stephanita, bornita II, calcocita II, covellita e prata nativa na Jazida Santa Maria.

AS CARACTERÍSTICAS E AS RELAÇÕES TEXTURAIS DOS MINERAIS OPACOS NAS VÁRIAS F F̃SeS DE MINERALIZAÇÃO A sucessão mineral e as paragêneses de cada fase de mineralização são discutidas a seguir com base nas relações texturais dos cimentes opacos e nas características do minério $\mathrm{Cu}-\mathrm{Pb}-\mathrm{Zn}$.

A Fase Eodiagnética a Mesogenética Nesta fase congregam-se todos os minerais opacos desenvolvidos concomitantemente à evolução dos cimentos transparentes, especialmente durante a eodiagênese e a mesogênese. Procura-se aqui enfatizar mais especificamente os aspectos minerográficos de cada mineral, responsáveis por certas peculiaridades texturais do minério.

Assim, a sucessão paragenética dessa primeira fase do processo de mineralização ocorreu na seguinte ordem:

"Martita" (= Hematita pseudomorfa sobre magnetita) A "martita" desenvolveu-se sobre magnetita de origem detrítica, que ocorre como cristais discretos e esparsos ou concentrados em níveis de minerais pesados, marcando o acamadamento de arenitos e conglomerados. As reações de substituição desenvolvem-se a partir dos planos (111) da magnetita, produzindo macias em xadrez. Alguns grãos mostram finas exsoluções de ilmenita segundo os planos octaédricos.

Com a mudança das condições oxidantes da deposição para as francamente redutoras da diagênese, magnetita e "martita" foram amplamente substituídas por sulfetos mesogenéticos. Assim, elas se encontram mais bem preservadas naquelas rochas que tiveram sua porosidade e permeabilidade drasticamente reduzidas pela compactação e infiltração mecânica de argilas, onde ocorrem como cristais relidos, parcialmente substituídos por neoformações argilosas. Os níveis arenosos e conglomeráticos limpos, sem argila intersticial e que mostram um amplo desenvolvimento das demais fases mesogenéticas, raramente apresentam magnetita. 
Hematita 1 A hematíta I forma prismas alongados, muitas vezes esqueléticos e/ou aciculares, que ocorrem como agregados na matriz (Fig. 6), como crescimentos secundários sobre a "martita", ou como inclusões nos sulfetos. Sua geração é atribuída à diagênese precose oxidante, pois a fragilidade dos prismas não suporta uma origem detrítica. A precipitação eodiagenética de hematíta caracteriza o Membro Vargas como um depósito tipo red bed.

Como a magnetita, a hematíta I encontra-se especialmente bem desenvolvida e preservada nos conglomerados e arenitos com abundante matriz argilosa e é consumida pela formação da clorita durante a mesogênese.

Rutilo/Anatásio O rutilo ocorre principalmente como agregados de cristais alongados, com disposição em treliça, que indicam seu desenvolvimento a partir de lamelas de exsolução de ilmenita em magnetita detrítica e são muito freqüentes tanto na ganga quanto como inclusões nos sulfetos. $\mathrm{O}$ anatásio ocorre como agregados de cristais tetragonais, cuja formação é igualmente atribuída ao início da diagênese, possivelmente também relacionando-se à alteração de minerais máficos detrítícos portadores de titânio, como biotita, titanita, magnetita etc.

Pirita/Marcassita A pirita I apresenta-se na forma de piritoedros ou cubos geralmente hipidiomórficos que ocorrem como pontuações dispersas pelos espaços intersticiais dos conglomerados e arenitos, ou que formam agregados de cristais localizados sobre intraclastos pelítícos, fragmentos de vulcânicas e micas detríticas alteradas (Foto 2), ou dispostos em níveis de concentração de minerais pesados segundo o acamadamento.

Ocasionalmente, ocorrem ainda agregados de cristais minúsculos de pirita com formas subcirculares que lembram pirita framboidal precoce, porém com tamanhos um pouco exagerados, provavelmente devido à recristalização.

$\mathrm{O}$ crescimento de cubos e piritoedros sobre antigos cristais da magnetita é evidenciado pela presença de uma textura particularmente interessante. Observa-se que a substituição da pirita por outros sulfetos algumas vezes se dá segundo planos bem definidos no interior dos cristais, resultando em placas de pirita com disposição octaédrica, que provavelmente refletem as formas cristalográficas de antigos cristais de magnetita (Foto 3). Por outro lado, essas relações também sugerem que os níveis impregnados de pirita sejam desenvolvidos a partir de leitos de magnetita detrítica segundo a estratificação.

Outra característica textural peculiar da pirita I é a ocorrência de cristais manchados, que ressaltam tanto estruturas coloformes típicas quanto zonas de crescimento (Foto 4). Tais feições podem representar interrupções durante o processo de crescimento dos cristais, gerando pulsos com pequenas variações composicionais do fluído percolante; ou podem ser devidas a variações na taxa de crescimento, resultando em imperfeições de retículo responsáveis pelo aspecto "sujo" dos cristais; ou ainda serem causadas pela inclusão de impureza durante a cristalização. No caso dos cristais manchados, é provável que a pirita framboidal precoce tenha atuado como núcleo de desenvovimento dos piritoedros ou cristais de marcassita, como documentam Ostwald \& England (1979). Assim, as manchas irregulares poderiam ser alternativamente interpretadas como remanescentes da textura porosa dos frambóides originais.

A marcassita é encontrada esporadicamente como inclusões na pirita I ou, ainda mais raramente, formando cristais independentes, porém parcialmente substituídos pela pirita. Enquanto a pirita possui uma composição $\left(\mathrm{FeS}_{2}\right)$ praticamente estequiométrica, a marcassita é um polimorfo levemente deficiente em enxofre. Segundo Craig \& Scott (1974), a temperaturas a partir de cerca de $150^{\circ} \mathrm{C}$ e em presença de excesso de enxofre, a marcassita inverte-se prontamente para pirita. Para
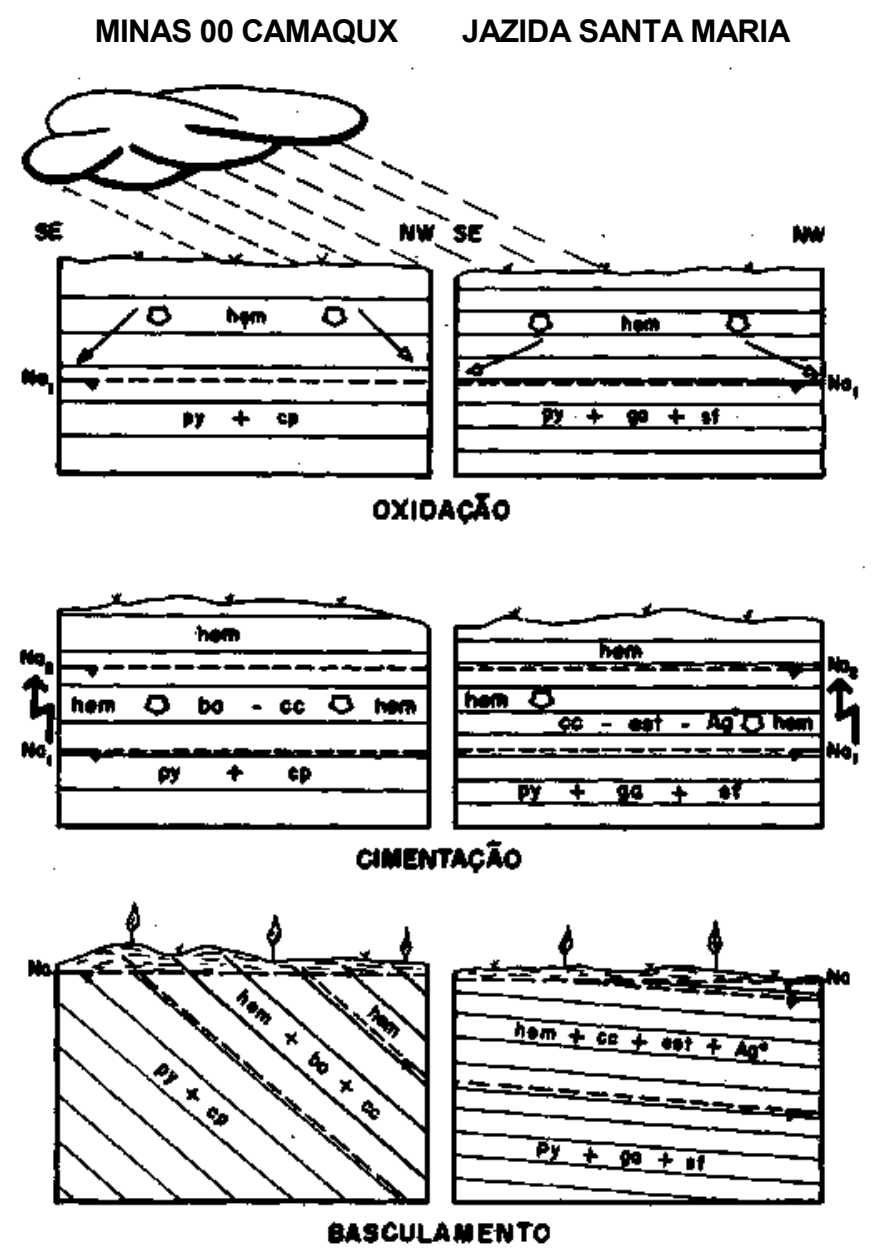

Figura 6 - Evolução da mineralização mesogenética com o desenvolvimento de zona de paleoxidação/cimentação seguida do basculamento das camadas

Figure 6 - Mesogenetic mineralization evolution with the paleo-oxidation/cementation zone development followed by bed tilting

temperaturas abaixo de $150^{\circ} \mathrm{C}$, os dados não são conclusivos. De qualquer forma, as inclusões de marcassita podem representar uma fase metaestável, desenvolvida localmente sob condições específicas de deficiência em enxofre, e que posteriormente se transformaram em pirita.

A pirita I desenvolve-se sobre os argilominerais e óxidos de ferro precoces e é envolvida pelos cimentes mesogenéticos tardios de quartzo, ankerita, sulfetos de $\mathrm{Cu}, \mathrm{Pb}$ e $\mathrm{Zn}$ e barita. Desse modo, sua formação é restrita aproximadamente ao estágio intermediário da mesogênese, sendo indubitavelmente anterior à mineralização.

A pirita I tem ampla distribuição tanto nos conglomerados e arenitos estéreis quanto nos mineralizados. É a única pirita que ocorre nas rochas de Jazida Santa Maria.

A FASE DE MINERALIZAÇÃO DIAGENÉTICA TARDIA E EPIGENÉTICA O estudo da evolução diagenética do Membro Vargas no Distrito de Camaquã revela que a mineralização sulfetada se formou nas etapas mais tardias da mesogênese, após o desenvolvimento de todos os cimentes transparentes. As relações texturais entre os sulfetos de $\mathrm{Cu}$, $\mathrm{Pb}$ e $\mathrm{Zn}$ e os cimentes transparentes que conduziram a essa conclusão estão detalhadamente descritas em Veigel (1989).

Como os minérios das Minas do Camaquã e da Jazida Santa Maria apresentam diferenças marcantes, a sucessão para- 
genética desta fase de mineralização será abordada separadamente para cada depósito.

1. A Jazida Santa Maria Galena e esfalerita, acompanhadas ou não de calcopirita, constituem os principais minerais de minério da Jazida Santa Maria. Aparecem na diagênese avançada como os últimos produtos da mesogênese. Podem ser citados dois modos extremos de individualização do cimento $\mathrm{Pb}-\mathrm{Zn}$ : (I) nos locais onde a evolução diagenética das rochas foi completa, os sulfetos envolvem ou mesmo corroem os crescimentos secundários tardios e cristais euédricos de quartzo, substituindo o cimento carbonático ferrífero ou ocupando os vazios deixados por sua dissolução, em típica precipitação na porosidade secundária. (II) nos locais com grande quantidade de argilas, que prejudicaram o desenvolvimento das etapas mais tardias da seqüência diagenética, os sulfetos penetram corrosivamente, consumindo tanto a matriz quanto os cimentes transparentes anteriores e o arcabouço.

Ambas, galena e esfalerita, ocorrem principalmente como núcleos isolados, que formam manchas micro a centimétricas dispersas pela rocha. $\mathrm{O}$ aumento da freqüência e do tamanho desses núcleos pode resultar numa disseminação contígua. Isso geralmente se dá ao longo de descontinuidades preexistentes, ressaltando estruturas primárias, como acamadamento, estratificação, laminação plano-paralela, laminações cruzadas cavalgantes etc. ou secundárias, como fraturas, fluidificações, slumps etc. Assim, grande parte do minério chamado maciço resulta da evolução extrema do processo de cimentação corrosiva, seja por percolação pelo acamadamento, em estruturação concordante, ou por fraturas e outras estruturas transversais, gerando corpos discordantes (Foto 5). Em suma, a distribuição do minério é intensamente condicionada pelas feições prévias da encaixante, tanto de natureza diagenética quanto sedimentológica.

Embora esfalerita e galena ocorram geralmente associadas, é difícil estabelecer uma cronologia relativa para os dois minerais, sendo que em uma única seção polida é comum a ocorrência de feições antagônicas que apontam ora para a precocidade da esfalerita em relação à galena, ora para uma relação inversa. Observa-se que, onde a esfalerita é dominante, a galena ocorre como massas com contornos côncavos, bruscos e irregulares, configurando uma textura corrosiva ou em cárie (Foto 6), que indica a substituição da galena pela esfalerita (Craig \& Vaughan 1981). Nas zonas onde a galena predomina, a esfalerita ocorre freqüentemente como inclusões com formas arredondadas, circulares ou em gotas que sugerem, por outro lado, a substituição da esfalerita pela galena (Foto 7). As texturas mais comuns, entretanto, são aquelas em que os sulfetos aparecem igualmente interpenetrados, sem feições marcantes de substituição. Segundo Craig \& Vaughan (1981), essas relações impedem a determinação de uma seqüência paragenética e podem indicar a cristalização simultânea dos minerais.

A interpretação mais razoável para esse conjunto de feições, portanto, parece ser a co-precipitação de ambos os sulfetos, com breves zonas de predomínio ou antecipações locais durante o processo de mineralização, capazes de propiciar o desenvolvimento local de texturas de substituição.

Esfalerita A esfalerita é o sulfeto mais abundante da Jazida Santa Maria, normalmente predominando sobre a galena. Ela forma massas de agregados de cristais muitas vezes poiquilotópicas que podem substituir integralmente a rocha. Ocorre sob duas formas muito características: (I) Como cristais translúcidos, isótropos, magnificamente zonados e com reflexões internas caramelo no centro a brancas nos bordos, constituindo massas límpidas, homogêneas, com poucas inclusões de ganga e outros sulfetos (Foto 8). Segundo Craig \& Vaughan (1981), cristais da esfalerita límpidos, zonados e praticamente puros são tipicamente desenvolvidos em espaços vazios. Assim, provavelmente esses cristais tenham crescido na porosidade secundária. (II) Como massas escuras, crivadas de inclusões submicroscópicas de calcopirita em texturas de crescimento epitaxial, que tem aspecto iridescente à luz natural e são falsamente anisótropas à luz polarizada e que também podem ser zonadas devido à remobilização da calcopirita para o bordo dos cristais. Essa esfalerita escura, que também tem um grande número de inclusões de ganga ou pinta I, parece substituir corrosivamente as rochas.

Cristais de esfalerita límpidos, zonados ou não, ainda precipitaram em substituição direta dos carbonates, especificamente ankerita. Neste caso, formam pseudomorfos perfeitos que herdaram os traços das clivagens romboédricas dos carbonates.

Galena A galena ocorre quase invariavelmente associada à esfalerita. Seu hábito mais comum é como massas irregulares circundadas pelo cimento esfalerítico, muitas vezes com textura em cárie.

Geralmente é a galena que substitui a pinta I, permeandose por fraturas ou descontinuidades de crescimento dos cristais, mesmo quando a esfalerita é o sulfeto preponderante. Na substituição dos silicates, a galena parece ser menos corrosiva que a esfalerita, amoldando-se principalmente na porosidade secundária delineada por cristais euédricos tardios de quartzo (Foto 7).

Calcopirita A calcopirita ocorre comumente como minúsculas pontuações dentro dos cristais de esfalerita, em textura típica de crescimento epitaxial (Craig \& Vaughan 1981), que podem estar remobilizadas, formando inclusões maiores. Inclusões de calcopirita na galena são muito raras. Ocasionalmente, entretanto, a calcopirita pode formar massas mais significativas, quando se associa indistintamente a ambos os sulfetos.

Novamente, a falta de texturas de substituição mais determinantes nos cristais maiores e a presença de feições de intercrescimento nas inclusões submicroscópicas são sugestivas da co-precipitação de calcopirita, galena e esfalerita.

Bornita I/Covellita A bornita I e a covellita foram encontradas associadas com ripas de hematita, esfalerita, calcopirita e pinta em uma feição muito localizada, como uma espécie de bolsão ou filonete de escape de fluidos em um arenito com aspecto fluidizado, mineralizado, dominantemente por galena.

2. As Minas do Camaquã Pirita, calcopirita, bornita e, muito localmente, calcocita, foram os principais sulfetos gerados durante a fase de mineralização diagenética tardia a epigenética nas Minas do Camaquã, ocorrendo como cimentos tardios nos conglomerados e arenitos que apresentam cores de redução diagenética de verdes e rosadas. Nos conglomerados amarronzados, a mineralogia dessa fase só é encontrada em locais restritos, especificamente em intraclastos pelíticos mineralizados por pinta, bornita e calcopirita relativamente menos porosos e permeáveis.

Similarmente ao que acontece na Jazida Santa Maria, os sulfetos de $\mathrm{Cu}$ e Fe também substituem corrosivamente os conglomerados e arenitos intensamente compactados e com abundante matriz argilosa, ou se infiltram pela porosidade secundária nas rochas que apresentam uma evolução diagenética mais completa. São particularmente notáveis as texturas de preenchimento da porosidade secundária em cavidades delineadas por perfeitos cristais euédricos de quartzo.

O minério de cobre dessa fase distribui-se predominantemente como disseminações esparsas ou contíguas. Merecem destaque as disseminações intensas, que ocorrem na Mina Uruguai, subterrânea, com geometrias alongadas, aproximadamente cilíndricas, de dimensões métricas e orientadas para NW segundo o mergulho das camadas. Essas disseminações, 
que localmente podem constituir um minério quase maciço, parecem representar zonas de percolação preferencial do fluido mineralizante, condicionadas por feições deposicionais e, sobretudo, diagenéticas.

Cabe ressaltar que a sucessão mineralógica e os aspectos texturais observados na maior parte dos filões de menor porte que atualmente estão sendo lavrados na Mina Uruguai coincidem com os descritos para o minério disseminado. Ainda mais, esses filões menores geralmente não mantêm um contato níti- do segundo um plano definido com as encaixantes. Ao contrário, seus contornos são irregulares, formando estreitas zonas de transição. Essas relações sugerem que tais filões possam ter evoluído concomitantemente à precipitação do minério disseminado pela percolação corrosiva dos fluidos mineralizantes segundo fraturas ou outras descontinuidades preexistentes. Assim, alguns dos filões menores não representariam um minério filoniano gerado por remobilização tectônica, mas uma disseminação forte, quase maciça, desenvolvida nas

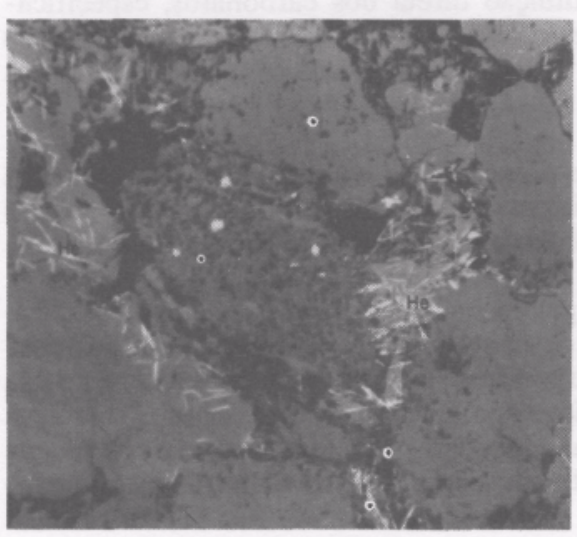

Foto 1

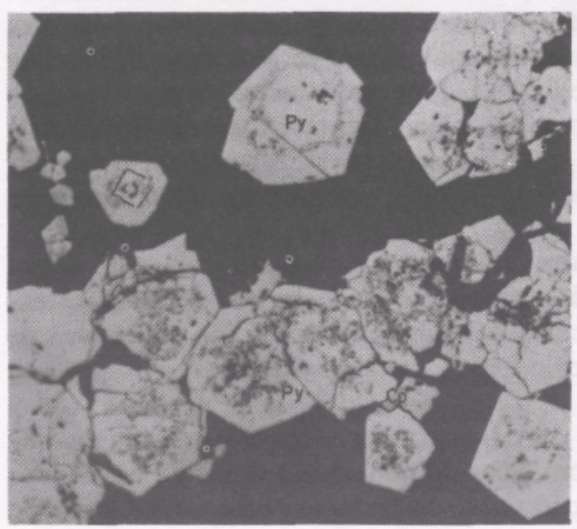

Foto 4

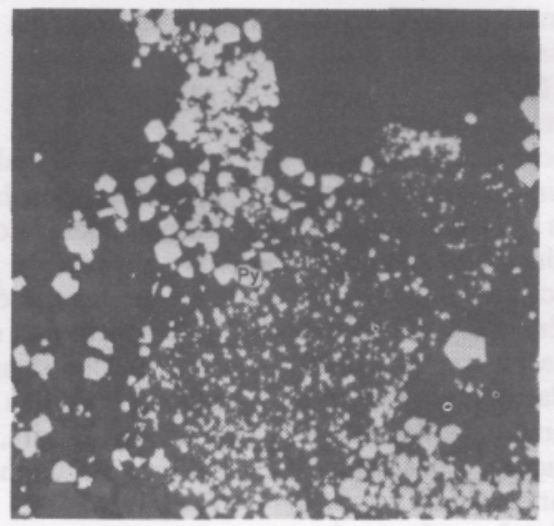

Foto 2

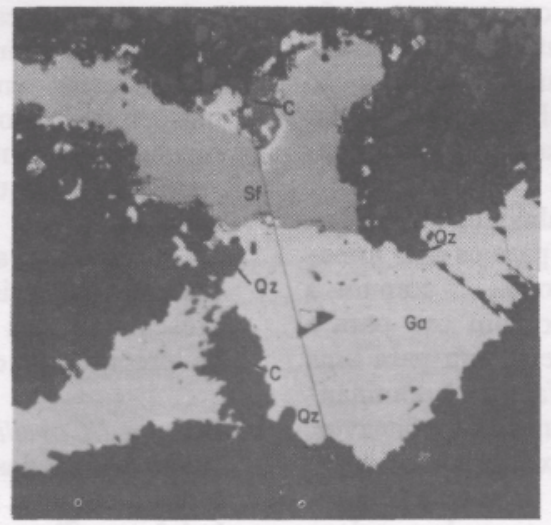

Foto 5

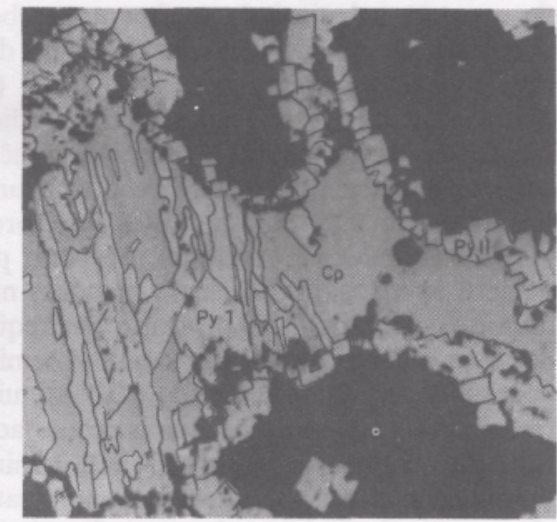

Foto 3

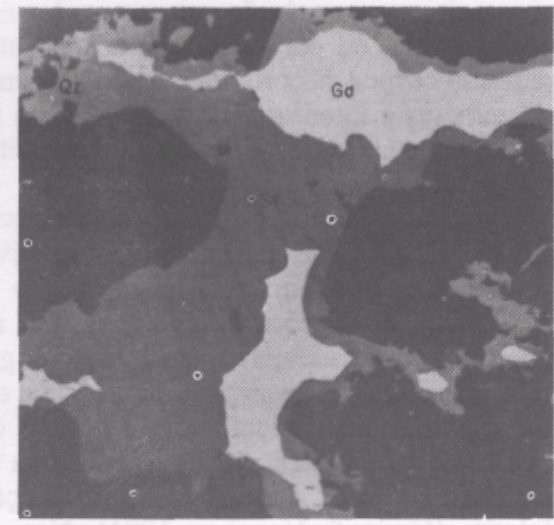

Foto 6

Prancha 1 - Abreviações utilizadas: $\mathrm{H}=$ hematita; $\mathrm{P}=$ pirita; $\mathrm{Ce}=$ calcopirita; $\mathrm{B}=$ bornita; $\mathrm{Cp}=$ calcocita; $\mathrm{Sf}=\mathrm{esfalerita}$; $\mathrm{G}=$ galena; $\mathrm{St}=$ stephanita; $\mathrm{Ag}=$ prata nativa; $\mathrm{Q}=$ quartzo; $\mathrm{C}=$ carbonato. $\mathrm{LN}=$ luz natural; $\mathrm{LP}=$ luz polarizada; Óleo $=$ objetiva de imersão em óleo; Ar = objetiva comum; $64 \mathrm{x}=$ aumento da ampliação. Foto 1. Cristais aciculares e esqueletaís de hematita I crescidos e preservados nos espaços intergranulares do arcabouço de arenito esverdeado com matriz argilosa mecanicamente infiltrada. LN, Ar. 64x; Foto 2. Piritoedros de pirita I crescidos de preferência sobre as porções mais argilosas de rocha: a) formando concentrações sobre intraclastos pelíticos e b) disseminados sobre a matriz argilosa inter granular. LN. Ar. $51 x$; Foto 3. Pirita I circundada por agregados de cubos de pirita II. A calcopirita desenvolve-se de preferência sobre a pirita I, evidenciando planos octaédrícos herdados das formas cristalográficas de magnetita detrítica (que foi substituída pela pirita I) e ressaltando as coroas de pirita II. LN. Ar. 102x; Foto 4. Nivel de concentração de pirita I no acamamento. Internamente, os piritoedros são manchados, algumas vezes mostrando zonas de crescimento. Substituição local por calcopirita. LN. Ar. 51x; Foto 5. Galena e esfalerita substituindo carbonato, preenchendo a porosidade secundária (evidenciada por alguns cristais automórficos de quartzo) e corroendo matriz e arcabouço. LN. Ar. 51 x; Foto 6. Galena e esfalerita como cimentos corrosivos ou localmente delineando ou envolvendo cristais automórficos de quartzo. Alguns contatos com textura em cárie. LN. Óleo. $201 x$

Plate 1 - Abreviations used: $\mathrm{H}=$ hematite; $\mathrm{P}=$ pyrite; $\mathrm{Ce}=$ chalcocite; $\mathrm{B}=$ bornite; $\mathrm{Cp}=$ chalcopyrite; $\mathrm{Sf}=$ sphalerite $; \mathrm{G}=$ galena; $\mathrm{E}=$ stephanite; $\mathrm{Ag}=$ native silver; $\mathrm{Q}=$ quartz; $\mathrm{C}=$ carbonate; $\mathrm{NL}=$ natural light; $\mathrm{PL}=$ polarized light; Oil = imersion objective; $\mathrm{Ar}=$ common objective; $64 \mathrm{x}=$ increase in the photo. Photo 1 . Hematite I needles and skeletal cristais grown and preserved in the framework inter-granular spaces of green sandstones with mechanically infiltred clay matrix. NL, Air;64 x; Photo 2.Pyrite I preferentially grown in clay rich rock parts: $a$ ) as concentrations over muddy clasts and $b$ ) scattered over the intergranular clay matrix. NL; Air; 51x; Photo 3. Pyrite I surrounded by pyrite II agregates. The chalcopyrite preferentially developes over the pyrite I, showing the octaedral planes inherited from detrital magnetite cristalographic planes and showing up the pyrite II rims. NL; Air; 102x; Photo 4. Level of pyrite I concentration in the bedding. Internally, the pyrite cristais are dirty, sometimes with growth zones. Local replacement by chalcopyrite. NL; Air; Six; Photo 5. Galena and sphalerite replacing carbonates, filling the secondary porosity (shown by some euhedral quartz crystals) and corroding both matrix and framework. NL; Air; Six; Photo 6. Galena and sphalerite as corrosive cements or locally delineating or eveloping quartz euhedral crystals. Some contacts with carious texture. NL; Oil; $201 \mathrm{x}$ 
fases anteriores.

Contrastando com as evidências de co- precipitação dos sulfetos de $\mathrm{Pb}$ e $\mathrm{Zn}$ na Jazida Santa Maria, as texturas do minério de cobre das Minas do Camaquã apontam para uma sucessão mineral mais diferenciada e mais bem desenvolvida.

Pinta II A distinção óptica entre pirita I e II é muito difícil, sobretudo quando analisadas isoladamente. A existência de duas fases de piritízação é revelada apenas nos locais em que ambas ocorrem associadas, quando suas diferenças se tornam evidentes. Nesses pontos, observa-se que a pirita I ocorre como massas com contornos irregulares ou piritoedrais, que são circundadas por agregados de pirita mais tardia na forma de rins ou coroas.

A pirita II forma cristais que tendem à euédrica cúbica e ocorrem isolados ou agrupados, envolvendo ou crescendo sobre massas mais antigas de pirita I.

Como mostra a foto 3 , os sulfetos posteriores substituem de preferência a pirita I, fazendo que as coroas de pirita II fiquem destacadas.

Calcocita I A calcocita I foi o primeiro sulfeto de cobre a ser precipitado nas Minas de Camaquã. Sua ocorrência é relativamente restrita, sendo encontrada em alguns níveis de arenitos rosados, bastante silicificados e livres de argila intersticial. Nessas rochas, forma um cimento discreto e esparso, que pode estar parcialmente substituído pela bornita I (Foto 9).

Localmente, a calcocita pode constituir um cimento primário importante: na Mina Uruguai, subterrânea, em alguns níveis róseos do Arenito Intermediário, a calcocita ocorre isolada (ou associada com alguma bornita), preenchendo pequenas cavidades ou vênulas alongadas segundo o acamadamento e delineadas por cristais euédricos de quartzo, em típica precipitação na porosidade secundária. Esses níveis mineralizados à calcocita são envelopados por conglomeados e arenitos mineralizados por pirita, bornita I e calcopirita. Pelo contexto em que ocorre e como não são encontradas evidências de oxidação e enriquecimento supergênico nem no minério nem nas encaixantes, essa calcocita é interpretada como sendo de origem primária, formada durante a fase de mineralização diagenética tardia a epigenética.

Cabe destacar que a calcocita I nunca foi encontrada associada à pirita I e II. Essa- relação parece indicar a reação preferencial do fluido mineralizante rico em cobre com o sulfeto de ferro resultando na formação de sulfetos de $\mathrm{Cu}$ e $\mathrm{Fe}$ (bornita I e calcopirita I), que comumente substituem a pirita.

Bornita I A bornita I ocorre como um cimento esparso, que engloba a calcocita I e é substituído por sulfetos mais tardios, como a calcopirita (Foto 9). Pode mostrar alguma alteração para covellita.

Comumente aparece em inclusões na calcopirita I, quando geralmente apresenta textura botrioidal, que pode estar ressaltadas por filmes de covellita. Resquícios de bornita I são também freqüentemente encontrados em fraturas ou outros planos de substituição de pirita I e II, mesmo nos locais de amplo predomínio de paragêneses posteriores, sobretudo da calcopirita. Essas texturas apontam para a substituição direta de pirita I e II pela bornita I.

Calcopirita A calcopirita, que substitui todas as paragêneses anteriores, é o sulfeto de cobre mais abundante dessa fase de mineralização. Ela ocorre freqüentemente como massas corrosivas que podem estar crivadas de inclusões de ganga e englobam a pirita e a bornita I (Foto 10).

É comum encontrar a calcopirita substituindo a pirita a partir de fraturas irregulares, zonas de crescimento e imperfeições de retículo, ou mesmo segundo planos octaédricos herdados de antiga magnetita (Foto 3 ).

Nas zonas em que a calcopirita é o sulfeto dominante, ob- serva-se que a bornita I é encontrada apenas como pequenas inclusões reliquiares muito freqüentes nas vênulas de substituição da pirita (Foto 10). Isso indica que a bornita I foi substituída de preferência em relação à pirita e pode ter tido uma distribuição bem mais ampla que a atual. Nas zonas onde predomina a bornita I, a calcopirita tipicamente ocorre como pequenas agulhas que invadem a bornita em textura de substituição bastante característica (Foto 11).

A FASE DE PALEOX IDAÇÃO/CIMENTAÇÃO Fortes evidências apontam para a existência da uma fase de paleoxidação/cimentação no depósito sulfetado do Distrito de Camaquã.

1. As Minas do Camaquã a. EVIDÊNCIAS DE CAM$P O$ A Mina Uruguai, a céu aberto, expõe magnificamente o pacote de rochas que compreende o topo do Arenito Intermediário, o Conglomerado Superior e a base do Arenito Superior. Nesse perfil, pode ser observada a transição de litologias caracteristicamente verdes (Arenito Intermediário e base do Conglomerado Superior) até rochas com coloração marcante marrom-escura, quase negras (a partir da porção central do Conglomerado Superior). Concomitantemente, a associação mineral varia de pirita-calcopirita-bornita nos conglomerados e arenitos reduzidos a hematita-bornita-calcocita nos oxidados. A transição é grosseiramente paralela ao acamadamento, encontrando-se atualmente basculada como todo conjunto do Membro Vargas, que mergulha cerca de $45^{\circ}$ para NW. Essas feições são interpretadas como devidas a superposição de uma zona de oxidação/cimentação sobre a mineralização da Fase Epigenética por oscilação do paleonível de água. O brusco soerguimento das litologias profundamente soterradas, como revela as feições diagenéticas, pode ser atribuído à forte tectônica operante durante a evolução da bacia ou simplesmente ao balanceamento isostático (Friedman 1987).

Como a oxidação acompanha aproximadamente o acamadamento, ela deve ter-se desenvolvido com as camadas em atitude mais ou menos horizontalizada, conforme o paleolençol freático. A oxidação/cimentação teria ocorrido, portanto, antes do basculamento tectônico do pacote para NW. Tais fatos, se analisados em conjunto com a discordância angular e erosiva entre a seqüência de leques aluviais mergulhante do Membro Vargas e a seqüência de sistema fluviais entrelaçados horizontalizada da Formação Guaritas, restringem a mineralização às litologias mais antigas. Fica assim caracterizada uma idade pré-Guaritas para os processos que conduziram à individualização das fases diagenética tardia e de paleoxidação/cimentação.

b. EVIDÊNCIAS MICROSCÓPICAS As relações texturais e a sucessão paragenética dos minerais opacos também revelam fortes evidências de uma fase de enriquecimento supergênico no minério de cobre.

Nos conglomerados rosados e esverdeados, o processo de mineralização encerrou-se após a formação de pirita, calcocita I, bornita I e calcopirita, da fase diagenética tardia a epigenética. Já nos conglomerados amarronzados, as paragêneses anteriores são completamente substituídas, mostrando uma evolução mineralógica peculiar com a formação de hematita II, bornita II, calcocita II e covellita II, sucessão que caracteriza a base de paleoxidação/cimentaçãó. $\mathrm{Na}$ transição das rochas reduzidas para as oxidadas, ocorrem paragêneses de ambas as fases: pirita e/ou calcopirita I são envolvidas por hematita II e/ou bornita II e calcocita II.

Excepcionalmente, também são encontrados intraclastos pelíticos mineralizados por pirita, bornita I e calcopirita dentro dos conglomerados amarronzados intensamente cimentados por bornita II e calcocita II. Esses pontos são interpretados como relidos da mineralogja desenvolvida na fase ante- 
rior, preservados da oxidação por sua permeabilidade relativamente mais baixa.

Hematita II A hematíta II é encontrada nos conglomerados amarronzados, mineralizados à base de bornita II e calcocita II ou, mais raro, associada a restos de sulfetos da fase anterior. Sua formação é atribuída à oxidação do minério da fase diagenética tardia a epigenética. As evidências texturais que sustentam essa interpretação são discutidas a seguir.

A hematita II relaciona-se com os sulfetos das fases anteriores sob três peculiares formas de ocorrência: (I) em conglomerados esverdeados, logo abaixo da zona de oxidação, a hematita II aparece ocasionalmente como agregados que envolvem cristais de pirita e massas de calcopirita, em nítida reação de substituição. (II) Em intraclastos pelíticos relictos mineralizados por pirita, bornita I e calcopirita, encontrados esporadicamente nos conglomerados amarronzados da zona de oxidação, a hematita II desenvolve-se como plaquetas em tor- no dos sulfetos, também em um processo de oxidação parcial. (III) Em conglomerados parcialmente amarronzados, na base da zona de paleoxidação, a hematita II ocorre como coroas envolvendo núcleos de pirita e ambas são substituídas por bornita II e calcocita II. A disposição subcircular dos agregados de hematita, muitas vezes circundando restos de pirita, sugere seu desenvolvimento nos bordos de antigos sulfetos, no caso piritoedros.

É nos conglomerados amarronzados, entretanto, que a hematita II se encontra amplamente difundida. Ali, ocorre como agregados de cristais que formam massas de textura esponjosa a ocuparem os espaços intergranülares do arcabouço, a exemplo dos sulfetos. Os cristais individuais constituem ripas ou plaquetas cujos tamanho e grau de cristalização diminuem dos bordos para o centro dos agregados (Foto 13). Assim, placas de hematita bem cristalizada, com extinção homogênea, circundam cristais finamente granulados, que formam massa de aspecto poroso e pulverulento. Tais texturas comprovam a

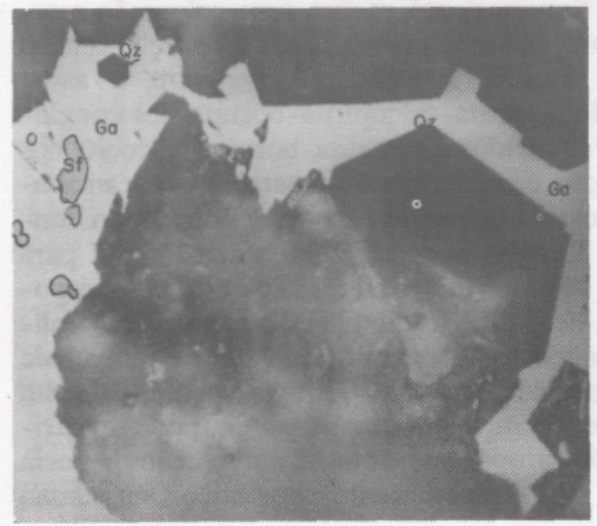

Foto 7

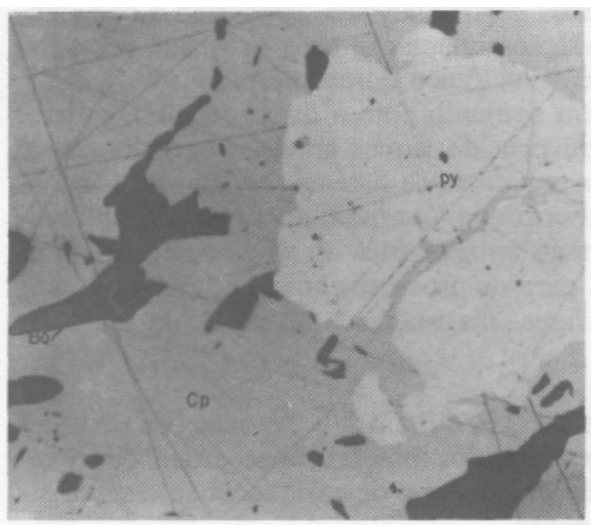

Foto 10

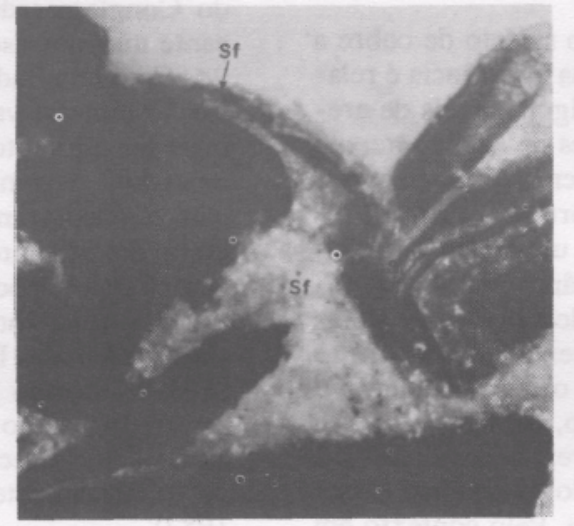

Foto 8

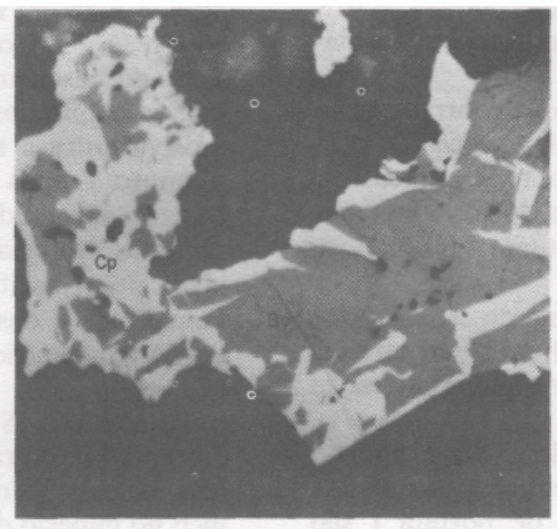

Foto 11

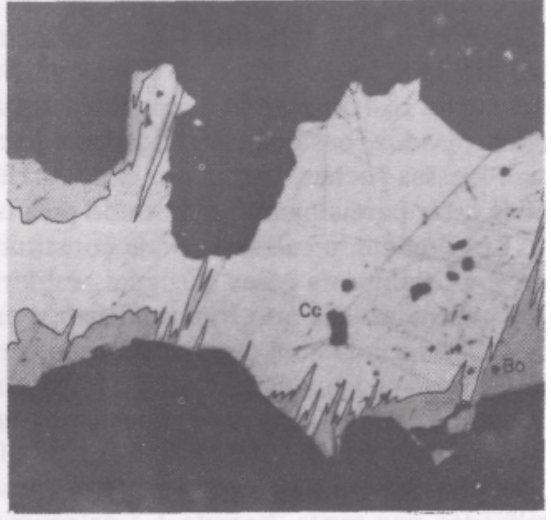

Foto 9

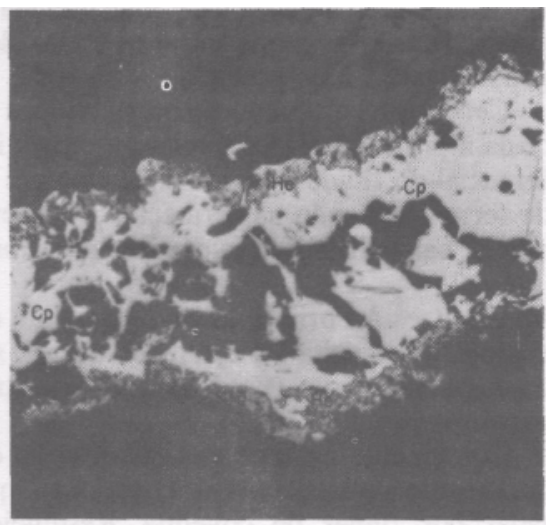

Foto 12

Prancha 2 - Foto 7. Galena preenchendo a porosidade secundária delineada por cristais automórficos de quartzo. As inclusões subcirculares sugerem a substituição de esfalerita por galena. LN. Óleo. $201 x$; Foto 8 . Cristais zonados de esfalerita, límpidos, com reflexões internas brancas nos bordos e desenvolvidos na porosidade secundária. LP. Óleo. 102x; Foto 9. Calcocita I parcialmente substituída por bornita I. A bornita I contém algumas minúsculas agulhas de calcopirita. LN. Óleo. 320x; Foto 10. Calcopirita como massa corrosiva crivada de inclusões de ganga, envolvendo e substituindo as piritas e a bornita I. LN. Óleo. 256x; Foto 11. Substituição de bornita I pela calcopirita. LN. Oleo. 320x; Foto 12. Oxidação incipiente da calcopirita com a formação de hematita II a partir dos bordos do cimento epigenético. LN. Ar. $80 x$

Plate 2 - Photo 7. Galena filling the secondary porosity delineated by quartz euhedral cristais. The subcircular inclusions suggest the substitution of sphalerite by Galena. NL; Oil; 201x; Photo 8 . Clear zonal sphalerite crystals, with white internal reflexions in the boundaries, grown in secondary porosity. PL; Oil; 102x; Photo 9. Chalcocite I partially replaced by bornite I. The bornite I has few small chalcopyrite needles. NL; Oil; 320x; Photo 10. Chalcopyrite as a corrosive mass with many inclusions, enveloping and replacing the pyrites and bornite I. NL; Oil; 256x; Photo 11. Substitution of bornite I by chalcopyrite. NL; Oil; 320x; Photo 12. Inicial oxidation of chalcopyrite with formation of hematite II from the boundaries of the epigenetic cement. NL; Air; 80x 
formação da hematita II por oxidação dos sulfetos anteriores. $\mathrm{O}$ desenvolvimento do processo a partir dos bordos em direção ao núcleo dos cristais favoreceu o crescimento das plaquetas de hematita como uma auréola em torno dos sulfetos oxidados.

Esse conjunto de relações demonstra o desenvolvimento da hematita II por oxidação gradual dos sulfetos da fase epigenética, de conglomerados esverdeados, que se mantiveram abaixo do paleolençol freático, aos fortemente amarronzados, que foram diretamente expostos na zona de oxidação.

Freqüentemente, as massas de hematita II estão parcialmente substituídas pelos sulfetos da zona de cimentação, evidenciando a elevação do paleonível freático após a oxidação dos sulfetos epigenéticos. Neste caso, a substituição da hematita II pela bornita II e calcocita II se dá a partir do núcleo dos agregados, onde os cristais têm granulometria mais fina e, portanto, maior superfície específica, que favorece a velocidade das reações. Como conseqüência, nos locais onde a cimentação por bornita II e calcocita II é importante, a hematita II ocorre apenas como plaquetas bem cristalizadas, formando agregados dispostos como tiras no interior dos sulfetos, que lhe são nitidamente posteriores. Esses cristais prismáticos são bem visíveis nos bordos das massas de bornita II e calcocita $\mathrm{u}$, sugestivamente delineando as formas dos antigos sulfetos da fase de mineralização anterior (Fotos 14 e 15).

A foto 16 ilustra a seqüência de processos de substituição na zona de oxidaçaõ/cimentação: observa-se a hematita II desenvolvida pseudomorficamente sobre piritoedros da fase de mineralização epigenética (reação desenvolvida na zona de oxidação) e sendo substituída por calcocita II e bornita II pelas zonas de crescimento remanescentes dos antigos cristais de pirita (reação da zona de cimentação).

Bornita II A bornita II forma massas que envolvem e consomem a hematita II e, excepcionalmente, podem conter inclusões remanescentes de pirita. Associa-se intimamente à calcocita II, que a substitui formando belas texturas mirmequíticas (Foto 14). Pode mostrar alguma alteração para covellita.

Calcocita II A calcocita II infiltra-se pela porosidade secundária delineando ou mesmo corroendo perfeitos crescimentos automórficos tardios de quartzo, ou formando manchas irregulares nos termos mais argilosos e menos porosos. Ocorre sobretudo como massas que incluem mirmequitos de bornita II e, quase invariavelmente, agregados esponjosos ou plaquetas relictas de hematita (Fotos 13, 14 e 15). Essa presença generalizada de hematita II indica que a maior parte dos sulfetos da zona de cimentação se desenvolveu nos mesmos locais ocupados pela paragênese da fase epigenética.

Como já se citou em alguns locais ocorrem importantes texturas de substituição pseudomórfica de antigos cristais de pirita, em que hematita II, calcocita II e bornita II se dispõem alternada e concentricamente, desenhando formas pentadodecaédricas que lembram piritoedros zonados (Foto 16).

Covellita A covellita desenvolveu-se localmente sobre bornita I e II e sobre calcocita II.

2. A Jazida Santa Maria a. EVIDÊNCIAS MESOSCÓPICAS A análise dos testemunhos de sondagem da Jazida Santa Maria também sugere o desenvolvimento da fase de paleoxidação/cimentação. Na porção estratigraficamente mais inferior, observam-se arenitos e conglomerados esbranquiçados, cinza-esverdeados ou rosados, mineralizados por pirita I, esfalerita e galena. Estas rochas passam para um pacote superior estéril, onde os níveis claros se intercalam com outros mais amarrronzados que não mostram indícios da presença de sulfetos de $\mathrm{Pb}$ e $\mathrm{Zn}$. Na transição do pacote inferior reduzido para o superior oxidado, entretanto, podem aparecer algumas concentrações de sulfetos de cobre e minerais de prata.

Essas feições sugerem a lixiviação do chumbo e do zinco por oxidação dos sulfetos na zona de oxidação, já que seus sulfatos são relativamente solúveis. $\mathrm{Na}$ zona de cimentação teria acontecido apenas o enriquecimento em cobre e a precipitação da prata, possivelmente remobilizada da estrutura da galena.

A cimentação supergênica é condicionada pelas paragêneses desenvolvidas na fase diagenética tardia a epigenética: os minerais de $\mathrm{Cu}$ e $\mathrm{Ag}$ ocorrem especificamente nos locais onde a galena foi relativamente mais expressiva e a calcopirita constituiu uma fase anterior importante, como acontece na área III. Nas áreas onde o cobre é originalmente desprezível e o zinco predominante sobre o chumbo, os metais foram lixiviados da zona de oxidação sem ter havido precipitações mais significativas na zonas de cimentação.

b. EVIDÊNCIAS MICROSCÓPICAS Na Jazida Santa Maria, observa-se o desaparecimento da paragênese esfaleritagalena-calcopirita da fase diagenética tardia epigenética, à medida que os conglomerados se tornam levemente amarronzados. Simultaneamente, surge a associação hematita II-stephanita-calcocita II-covellita II-prata nativa, caracterizando o desenvolvimento da fase de paleoxidação/cimentação.

Em relação às Minas do Camaquã, as transformações ocorridas foram menos intensas: apesar de a galena e a esfalerita terem sido completamente alteradas, ainda são comumente encontrados agregados de pirita intacta ou parcialmente oxidada ou sendo substituída pelos cimentes supergênicos (Foto 17). O desenvolvimento da hematita II é também muito mais restrito que nos conglomerados da Mina Uruguai.

Hematita II A hematita II é um produto de oxidação da pirita I. Cresce irradiando-se a partir do núcleo poroso de agregados de pirita framboidal recristalizada ou substitui pseudomorficamente cristais cúbicos ou piritoedrais maiores, geralmente salientando suas zonas de crescimento em um processo de oxidação ainda incipiente.

A hematita II é envolvida pelos minerais das paragêneses posteriores, especialmente pela calcocita II.

Stephanita A stephanita é rara, sendo encontrada associada à calcocita II em arenitos rosados quase sem pirita I e hematita II.

Forma manchas esparsas, que se destacam por sua birreflectância distinta em tons violáceos e pela forte anisotropia. É substituída pela calcocita II ou diretamente pela prata nativa.

A foto 18 mostra a corrosão de uma massa de stephanita pela calcocita II; essa feição sugere que esse sulfoantimonieto de prata possa ter tido uma distribuição mais significativa.

Bornita II Ocorre esporadicamente associada à calcocita II, como inclusões.

Calcocita II É o mineral mais comum da fase de paleoxidação/ cimentação na Jazida Santa Maria. Forma cimentes esparsos, que ocupam parte da porosidade secundária liberada pela lixiviação dos sulfetos de $\mathrm{Pb}$ e $\mathrm{Zn}$ ou outros materiais transparentes anteriores. Comumente, mostra-se alterada para covellita.

A calcocita II envolve a hematita II e a stephanita (Fotos 17 e 18) ou substitui diretamente os sulfetos das fases anteriores. Ela é encontrada sobre cristais ou agregados de pirita I, ressaltando suas zonas de crescimento ou planos de disposição octaédrica herdados de magnetita detrítica.

Covellita A covellita é estritamente associada à calcocita II.

Prata Nativa A prata nativa ocorre como massas compactas que podem estar isoladas ou substituindo todas as paragê- 
neses anteriores. Neste caso, a prata nativa engloba a pirita I, permeando-se por entre os agregados de cristais, comumente destacando sua estrutura zonada, a exemplo da calcocita II (Foto 17); também envolve a stephanita e substitui a calcocita II muitas vezes com textura em cárie.

Provavelmente a prata tenha sido remobilizada a partir da estrutura da galena, que foi solubilizada na zona de paleoxidação.

Sintetizando, o desenvolvimento da fase de paleoxidação/cimentação em ambos os depósitos teve diferenças significativas, reveladas por feições de mega a microscópicas, como esquematiza a figura 6 . Tenta-se a seguir discutir os parâmetros que condicionaram essas variações.

A característica talvez mais marcante dos conglomerados expostos na Mina Uruguai, que foram submetidos à zona de paleoxidação/cimentação, é sua cor marrom-escura, quase negra, devida à extensiva formação da hematita II por oxidação total dos sulfetos de $\mathrm{Fe}$ e $\mathrm{Cu}$ anteriores. A cimentação por bornita II e calcocita II nessas rochas intensamente amarronzadas evidencia o recobrimento da zona de paleoxidação pela zona de paleo-cimentação, por elevação do antigo nível freático.

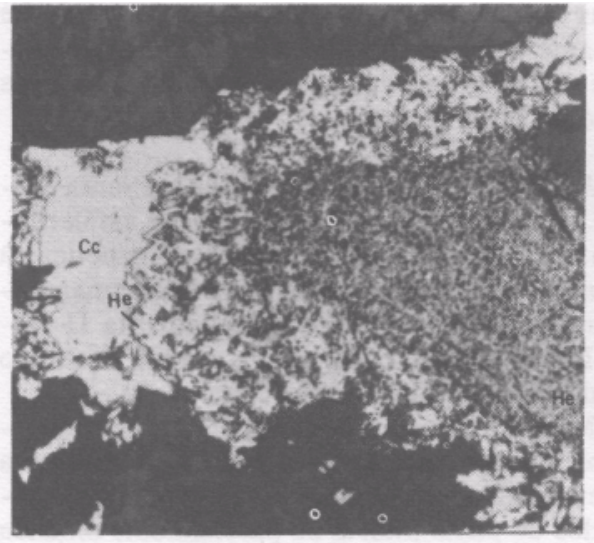

Foto 13

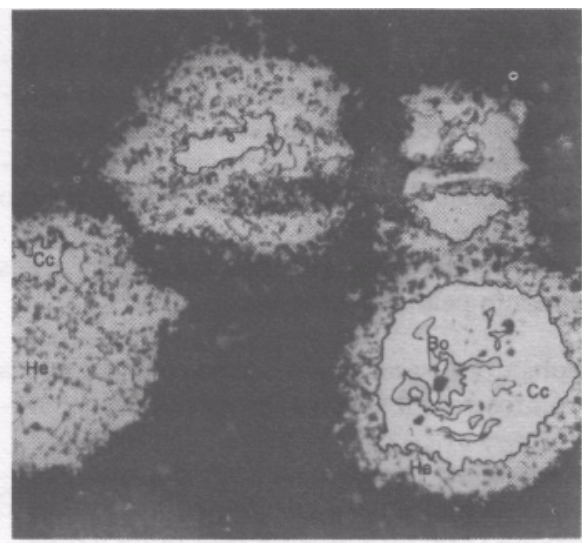

Foto 16

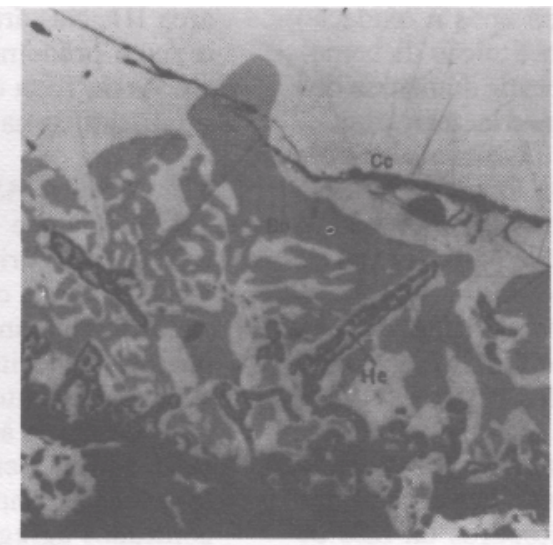

Foto 14

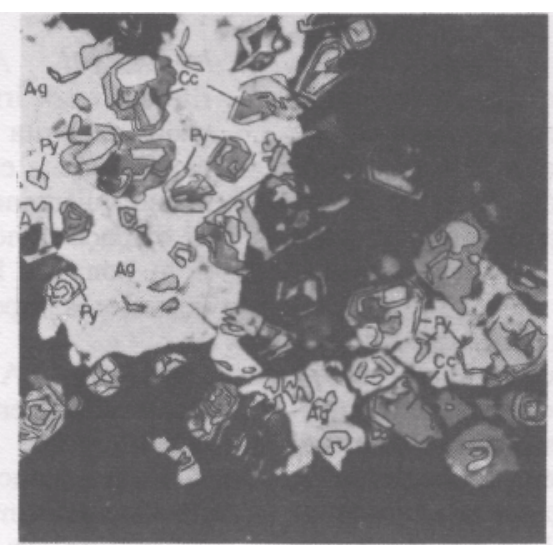

Foto 17

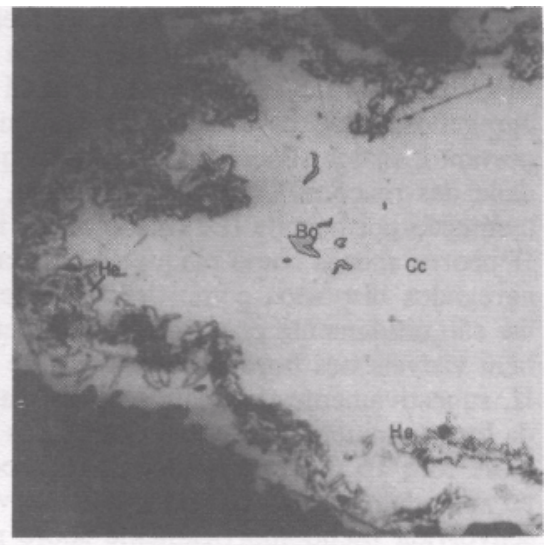

Foto 15

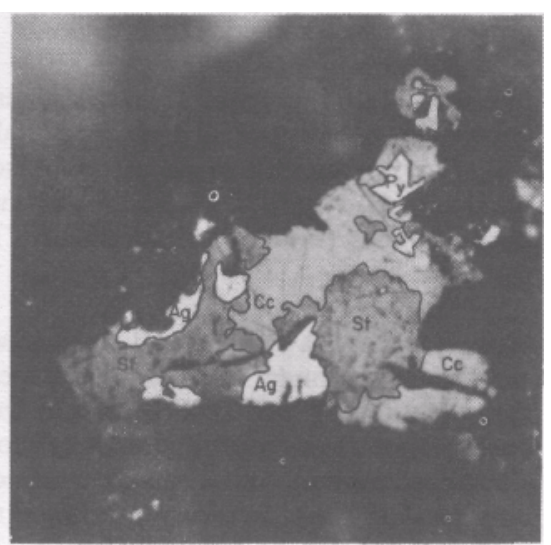

Foto 18

Prancha 3 - Foto 13. Oxidação total dos sulfetos da fase epigenética. A hematita II forma massas pulverulentas de agregados de minúsculos cristais circundados por plaquetas maiores e bem cristalizados e substituidas parcialmente pela calcopirita II, LN. Ar. 128x; Foto 14. Texturas mirmequiticas de substituição da bornita II por calcocita II. São observadas também tiras de agregados relictos de hematita II. LN. Oleo. 102x; Foto 15. Calcocita II com bornita II subordinada substituindo a hematita II. Observe que a hematita II ocorre como tiras de agregados de plaquetas dispostas nos bordos de calcocita II, sugestivamente delineando as formas dos antigos sulfetos epigenéticos oxidados. A calcocita II teria substituído de preferência o núcleo pulverulento dos agregados de hematita II (Ver figura 18). LN. Óleo. 102x; Foto 16. Hematita II desenvolvida pseudomorficamente sobre pintas. O núcleo dos piritoedros oxidados, onde a hematita II tem granulação mais fina, é substituído por bornita II e calcocita II. LN. Oleo. $256 x$; Foto 17. Calcocita II substituindo pirita I ressaltando suas zonas de crescimento e sendo envolvida pela prata nativa. São observados ainda alguns restos de stephanita. LN. Oleo. 560x; Foto 18. Substituição corrosiva de stephanita por calcocita II. Ocorrem também restos de pirita I. A prata nativa substitui todos os minerais anteriores. LN. Óleo. $560 x$

Plate 3 - Photo 13. Total oxidation of the epigenetic phase sulfides. The hematite II occurs as porous mass of small crystals agregates, surrounded by bigger and well crystallized ones and partially replaced by chalcocite IT. NL; Air; 128x; Photo 14. Mirmekite texture of substitution of bornite II by chalcocite II. Observe the ribbons of relict hematite aggregates. NL; Oil; 102x; Photo 15. Chalcocite TT with some bornite TT replacing hematite IT. Observe the hematite TT as aggregate ribbons displayed in the boundaries of chalcocite TT, probably delimitating the shapes of the oxydized old epigenetic sulfides. The chalcocite Ilv ould have partially replaced the porous nucleous of the hematite aggregates (see figure 18) NL; Oil; 102x; Photo 16. Hematite II as pseudomorphs over pyrite. The oxydized pyrite nuclei, where the hematite TT has thinner sizes, are replaced by bornite TT and chalcocite IT. NL; Oil; 256x; Photo 17. Chalcocite IT substituting pyrite I showing up its grown zonafions and being replaced by native silver. See also remains of stephanite. NL; Oil; 560x; Photo 18. Corrosive substitution of stephanite by chalcocite IT. Remains of pyrite TT also occur. The native silver replaces all the previous minerals. NL; Oil; 560x 
Por outro lado, a precipitação de stephanita-calcocita IIprata nativa na zona de paleoxidação/cimentação na Jazida Santa Maria dá-se sobre rochas que mostram uma coloração clara, apenas localmente um pouco amarronzada pelo desenvolvimento incipiente de hematita II. Essas feições sugerem que os processo tenham sido menos intensos, o que pode ser devido a duas razões principais:

I. Na Jazida Santa Maria, predominam os arenitos finos a médios sobre níveis de conglomerados a granules e seixos, que, por sua granulometria mais fina, devem ter sido bem menos permeáveis que os grossos conglomerados da Mina Uruguai. Dessa forma, a pirita remanescente pode traduzir a existência de porções das rochas preservadas da percolação das águas superficiais oxidantes, provavelmente em função da presença abundante de argilas intersticiais.

II. O intenso desenvolvimento da hematita II nos conglomerados da Mina Uruguai, contrastante com a formação escassa de hematita na Jazida Santa Maria, relacionado às paragêneses presentes em cada depósito no momento da sobreposição da zona de oxidação. A oxidação de pirita I e II, bornita I e calcopirita I, distribuídas como extensas massas cimentando o arcabouço dos grossos conglomerados, permitiu a formação de grande quantidade de óxidos de ferro; já na Jazida Santa Maria, apenas algum ferro pôde ser liberado da pirita I, disseminada de preferência.nas porções mais argilosas e impermeáveis dos arenitos.

Assim, as diferenças observadas são conseqüência da granulometria relativa dos sedimentos e da quantidade de ferro disponível nos sulfetos oxidados.

\section{A FASE DE REMOBILIZAÇÃO TECTÔNICA}

\section{AS MINAS DO CAMAQUÃ}

O minério filoniano das Minas do Camaquã vem sendo lavrado há cerca de um século. Apesar de os filões mais possantes já estarem exauridos, soube-se que as maiores concentrações de cobre do distrito, particularmente localizadas nas minas Uruguai e São Luís, eram encaixadas em dois principais sistemas de falhas e fraturas: (I) N50W; 71SW e N60-68W; 60-89NE; e (II) N20W; 81NE (Bettencourt 1972).

Bettencourt (op. cit.), que estudou a mineralização filoniana das Minas do Camaquã (na época, o único tipo de minério conhecido), reconheceu quatro fases de mineralização, por ele denominadas:

I. Fase principal da pirita, em que houve a alteração hidrotermal das paredes com formação de caulinita e "sericita", seguida da deposição de quartzo e pirita.

II. Fase principal da calcopirita, em que se depositaram extensivamente calcopirita e uma pequena quantidade de bornita, acompanhadas por quartzo.

III. Fase da hematita, quando se formou clorita nas paredes dos veios e nas zonas brechadas, seguida de hematita especular e algum quartzo.

IV. Fase final, caracterizada por uma recorrência da mineralização com a deposição de pirita seguida por calcopirita, esta acompanhada por quartzo, calcita e barita.

Esse minério á base de pirita, calcopirita e quartzo ocorre em filões abertos em encaixantes brechadas e silicificadas, principalmente na Mina São Luís. Atualmente são conhecidos também filões à base de bornita, calcocita e hematita, que em sua maior parte ocorrem associados a uma estrutura em Y, definida pelas chamadas falhas de gravidade e calcocita. Nesses filões com bornita, que podem estar acompanhados por calcita e barita, as paredes encaixantes são bastante irregulares e marcadas por generalizada argilização.

A característica talvez mais conspícua dos filões é a de conterem a mesma mineralogia do minério disseminado das encaixantes que lhes são contíguas. Dessa forma, quando eles cortam conglomerados e arenitos róseos ou esverdeados, são preenchidos por pirita, hematita, calcopirita e bornita, paragê- nese idêntica à da fase de mineralização epigenética e que parece corresponder à seqüência descrita por Bettencourt (1972); quando atravessam os conglomerados amarronzados, tipicamente contêm bornita, calcocita e hematita, associação semelhante à da fase de paleoxidação/cimentação. Ainda, os filões sistematicamente adelgaçam-se ou mesmo desaparecem quando atravessam encaixantes estéreis.

Na exposição da Mina Uruguai, a céu aberto, observa-se que a falha de gravidade desloca a zona de paleoxidação/cimentação. Essas feições corroboram que a fase filiniana ocorreu por remobilização tectônica após a fase de paleoxidação/cimentação, provavelmente na época do basculamento dos blocos para NW.

\section{A JAZIDA SANTA MARIA}

Na Jazida Santa Maria, corpos de minério maciço mais expressivos, que caracterizem remobilizações posteriores, são relativamente restritos. Apenas alguns furos de sonda atravessaram raros níveis decimétricos de galena e esfalerita praticamente maciços, mas que, na campanha de sondagem efetuada, não mostraram continuidade lateral. No mais, o minério remobilizado consiste apenas em filonetes de esfalerita e galena. A baixa expressão da fase filoniana na Jazida Santa Maria pode ser relacionada à ausência de falhamentos mais efetivos, que propiciassem a remobilização dos sulfetos de $\mathrm{Pb}$ e $\mathrm{Zn}$. Ali, as camadas mergulham suavemente (entre $5^{\circ}$ e $10^{\circ}$ para NW), contrastando com a forte inclinação do pacote das minas (entre $30^{\circ}$ e $45^{\circ} \mathrm{NW}$ ). Isso parece reforçar que a fase de remobilização tectônica ocorreu no momento do basculamento do bloco das minas para NW e, portanto, antes da deposição da Formação Guaritas.

\section{CONCLUSÕES SOBRE A EVOLUÇÃO DA MINERA- LIZAÇÃO Cu-Pb-Zn DO DISTRITO DE CAMAQUÃ}

1. A precipitação dos sulfetos de $\mathrm{Fe}, \mathrm{Cu}, \mathrm{Pb}$ e $\mathrm{Zn}$ foi o último evento da mesogênese da evolução diagenética do Membro Vargas. Durante a fase de mineralização diagenética tardia a epigenética houve a precipitação da sucessão calcocita I-bornita I-calcopirita nas Minas do Camaquã e da paragênese galena + esfalerita \pm calcopirita na Jazida Santa Maria. A mineralização tem uma distribuição bastante complexa que reflete características e feições deposicionais intensamente modificadas pelos processos diagenéticos. As duas principais formas de ocorrência são: (I) nos locais em que a seqüência diagenética foi bem desenvolvida os sulfetos preenchem a porosidade secundária como precipitação direta ou substituindo a ankerita; (II) onde a evolução foi restringida ou abortada devido à grande infiltração mecânica de argilas ou à intensa cimentação silicosa precoces, os sulfetos foram corrosivos sobre os silicates. As, maiores concentrações do minério disseminado estão nos níveis onde a porosidade secundária foi mais bem desenvolvida. Grande parte do minério chamado maciço resulta do processo de cimentação corrosiva transgredindo os limites dos poros secundários.

2. Após a fase de mineralização diagenética tardia a epigenética, as rochas foram soerguidas e submetidas a uma zona de alteração superficial, onde os sulfetos mesogenéticos foram lixiviados ou alterados para hematita II. Subseqüentemente, houve a ascensão do paleolençol freático e a precipitação da sucessão bornita II-calcocita II-covellita sobre as rochas oxidadas das Minas do Camaquã e stephanita-bornita II-calcocita II-covellita-prata nativa naquelas da Jazida Santa Maria. A distribuição dos sulfetos da fase de paleoxidação/cimentação segue basicamente o mesmo controle que as paragêneses mesogenéticas.

A paleoxidação/cimentação telodiagenética das rochas do Membro Vargas implica que uma pilha de, no mínimo, 5.000 $\mathrm{m}$ de estratos foi removida para trazer as rochas profundamente soterradas na mesogênese até a superfície. Isso comprova o importante significado sedimentológico e estratigráfi- 
co da discordância erosiva entre a Unidade Vargas e a Formação Guaritas.

3. O arqueamento ou basculamento das camadas ocorreu após o desenvolvimento da fase de paleoxidação/cimentação (a zona de paleoxidação/cimentação acompanha o acamadamento que mergulha para NW) e propiciou a remobilizáção fíloniana do minério nas regiões que foram mais tectonizadas, como aconteceu nas Minas do Camaquã. A deposição dos sedimentos continentais da Formação Guaritas ocorreu quando as camadas Vargas já estavam inclinadas, isto é, só após a fase de remobilizáção tectônica. Assim, a mineralização $\mathrm{Cu}-\mathrm{Pb}-$ $\mathrm{Zn}(\mathrm{Ag})$ fica restrita na unidade transicional mais antiga.

4. O modelo evolutivo para a mineralização do Distrito de Camaquã está representado na figura 7 e compreende cinco etapas: (1) a deposição, seguida de eodiagênese oxidante a lateralmente redutora; (II) o soterramento profundo com o de- senvolvimento dos minerais mesogenéticos, culminando com a fase de mineralização diagenética tardia a epigenética; (III) o soerguimento telodiagenétíco com o desenvolvimento da fase de paleoxidação/cimentação; (IV) o basculamento ou arqueamento das camadas concomitante à fase de remobilizáção tectônica das paragêneses anteriores; e (V) a deposição da Formação Guaritas após o encerramento da evolução da mineralização.

Agradecimentos Os autores deste trabalho, desenvolvido com o auxílio do CNPq (Processo $n$ - 40134-87), agradecem o apoio recebido da Companhia Brasileira do Cobre (CBC) e especialmente a colaboração dos Geólogos Marcelo Ribeiro, Gilson Teixeira, Waldemar Salomão B adi, Nilson Dornelles e Forgiarini.

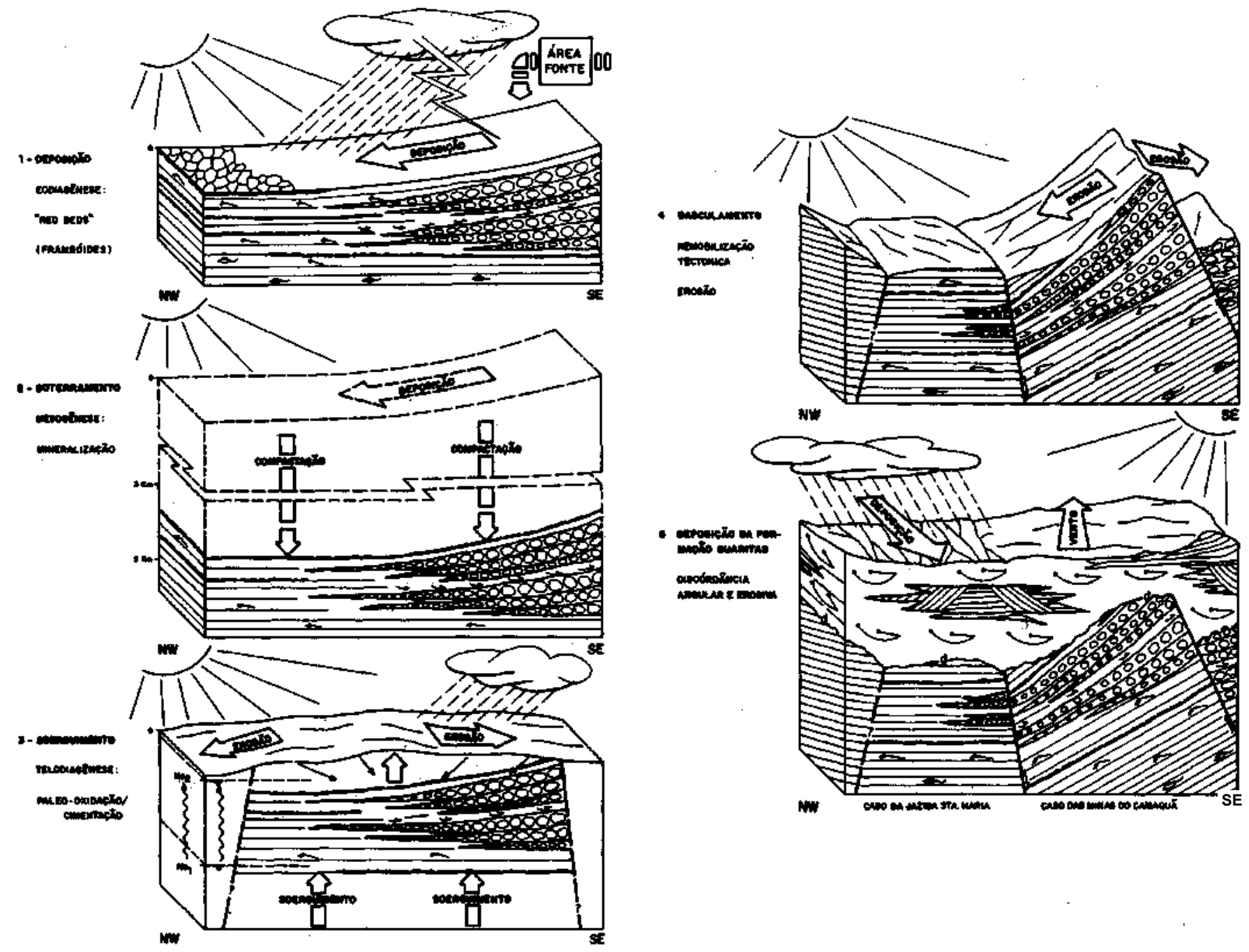

Figura 7 - Modelo evolutivo esquemático para a mineralização Cu-Pb-Zn do Distrito de Camaquã, RS Figure 7 - Schematic evolutionary model for the $\mathrm{Cu}-\mathrm{Pb}-\mathrm{Zn}$ mineralization of the Camaquã District, RS 


\section{REFERÊNCIAS BIBLIOGRÁFICAS}

BADI, W.S.R. 1983. Mineralização de chumbo e zinco em arenitos do Distrito de Camaquã. Porto Alegre, 137 p. (Dissertação de Mestrado, UFRGS) (inédito)

BETTENCOURT. J.S. 1972. A mina de Cobre de Camaquã, RS. São Paulo. 175 p. (Tese de Doutorado, USP) (inédito).

CRAIG, J.R. \& SCOTT, S.D. 1974. Sulfide phase equilibria. In: RIBBE, P.M. (ed) Sulfide Mineralogy, vol. 1, 4th. ed. Mineralogical Society of Âmerica, short course notes, v. 1, cap. 5, CS1-CS110.

CRAIG, J. \& VAUGHAN, DJ. 1981. Ore microscopy and ore petrography. Wiley \& Sons. $406 \mathrm{p}$.

FACCINI, V.F.; PAIM, P.S.G.; FRAGOSO CÉSAR, A.R.S. 1987 Análise faciológica das molassas Brasilianas na Região das Minas do Camaquã, RS. In: SIMP. SUL-BRAS. GEOL. 3, Curitiba 1987.Anais... Curitiba, SBG. v. 1, p. 75-91.

FRAGOSO CÉSAR, A.R.S; FACCINI, V.F.; PAIM, P.S.; LA VINA E.L.; ALTAMIRANDO, J.A.F. 1985. Revisão da estratigrafia das molassas do Ciclo Brasiliano no Rio Grande do Sul. In: SIMP. SUL-BRAS. GEOL., 2, Florianópolis, 1985. Anais... Florianópolis, SBG. p. 477-491

FRIEDMAN, G.M. 1987. Deep-burial diagenesis: its implications for vertical movements of the crust, uplift of the lithosphere and isostatic unroofing - a review. Sediments. Geology, 50:67-94.

JOST, H. 1984. Sedimentação e vulcanismo durante o ciclo Brasiliano no Rio Grande do Sul: uma revisão. In. CONGR. BRÁS. GEOL.,
33, Rio de Janeiro, 1984. Anais... Rio de Janeiro, SBG. v. 2, p. 3241-3257.

LEINZ, V.\& ALMEIDA, S.C. 1-941. Gênese da Jazida de Cobre de Camaquã. Porto Alegre, Secret Ind. Com. R.S., DNPM. (Boi. n.8).

RIBEIRO, M J. 1978a. Mapa provisional do cobre no Escudo Sul-Rio-Grandense. Nota explicativa. Seção Geologia Econômica, no. 1. Brasília, DNPM-MME. (Série Geologia 3).

RIBEIRO. MJ. 1978b. Problemas ligados à presenca do cobre sedimentar no Rio Grande do Sul. In: CONGR. BRAS. GEOL. 30, Recife, 1978. Anais... Recife, SBG. v. 6, p. 2520-2533.

RIBEIRO, M.; BOCCHI, P.R.; FIGUEIREDO FILHO, P.M.; TESSARI, V.F. 1966. Geologia da Quadrícula de Caçapava do Sul-RS, Brasil. DNPM/DFPM, Boletim Div. Fom. Prod. Min. Brás., Rio de Janeiro, 127:1-232.

TEIXEIRA, G; GONZALES, A.P.; GONZALES, M.A.; LIGHT, O.B. 1978. Contribuição ao estudo da mineralizações cupríferas disseminadas no Distrito das Minas do Camaquã. In: CONGR. BRÁS. GEOL., 30, Recife, 1978. Anais... Recife, SBG. v.6, p. 1644-1654.

MANUSCRITO A541

Recebido em 25 de maio de 1988 Revisão do autor em 05 de outubro de 1989 Revisão aceita em 05 de outubro de 1989 